\title{
PÄÄKIRJOITUS
}

\section{PANDEMIAN LOPUN ALKU}

\author{
PANDEMIA-TEEMANUMERO - OSA II
}

Vuosi 2021 alkoi lupaavilla rokoteuutisilla. Jo pandemiavuoden loppupuolella suurten lääkealan yritysten johtajat ja poliitikot julistivat yhteen ääneen rokotteiden kehittämisen lupaamaa "pandemian lopun alkua”. Tammikuussa 2021 yhä useampi rokote COVID-19-virusta vastaan on saanut myyntiluvan ja rokotusjärjestyksen kärkipäässä olevia ryhmiä on päästy rokottamaan ympäri maailmaa.

Rokottaminen merkitsee monella tapaa paluuta normaaliin elämään. Samalla se kuitenkin palauttaa meidät paradoksaalisesti pandemian alkuvaiheen tilanteeseen, jossa kysymys normaalin ja poikkeusolojen välisestä suhteesta oli polttava niin käytännössä kuin teoreettisesti: Mihin pandemian sanelemien toimien välttämättömyys oikein perustuu? Miten ymmärtää pandemian luonne ehdottoman tieteellisenä tosiasiana ja samalla kertaa kiistämättömänä yhteiskunnallisena ilmiönä ja sosiaalisena faktana? Pandemiavuoden opetusten jälkeen nämä kysymykset johdattavat pohtimaan kolmea toisiinsa kytkeytyvää teemaa: ilmiötä jota voisi kutsua "valtion haluksi", pandemia-ajan korostamaa tilastotieteiden yhteiskunnallista merkitystä eli "suurten lukujen politiikkaa" sekä yhteiskunnallisen ajattelun roolia.

\section{VALTION HALU}

Pandemian eri vaiheiden väliset siirtymät, sen aallot ja nyt julistettu "lopun alku" näyttävät tapahtuvan niiden jännitteiden kautta, jotka olivat olemassa jo ennen COVID-19-pandemiaa mutta joita se korosti entisestään. Yksi keskeinen jännite liittyy käsitykseen valtiosta ja sen roolista. Keväällä 2020 valtion teki pandemiatilanteessa liikaa: valmiuslait ja karanteenit rikkoivat kansalaisten ihmisoikeuksia, yrittämisen ja elinkeinojen vapautta ja uhkasivat myös perustavammalla tavalla hyvän elämän ehtoja. Samaan aikaan ja erityisesti vuoden 2021 vaihteessa saman valtion sanottiin tekevän liian vähän: väestö tulisi saada rokotettua nopeammin ja taloudelle olisi pitänyt jo kauan sitten antaa huomattavasti voimakkaampia piristysruiskeita.

Globaalilla tasolla useiden yksityisten rokotevalmistajien tuotanto, välitys ja jakeluinfrastukuurit toimivat niin sanottujen vapaiden markkinoiden logiikan mukaisesti, joissa eri kansallisvaltiot kilpailevat valtansa ja maksukykynsä mukaan suuryritysten patenteilla suojaamista rokoteannoksista. Koska vapaat markkinat eivät näytä kuitenkaan pystyvän toimittamaan tarpeeksi rokotteita edes Euroopan maille niiden isoja rahoja vastaan, puhe aktiivisemmasta talouden julkisesta ja valtiollisesta kontrollista on jälleen lisääntynyt. Kaikista oikeistolaisista ja vasemmis- 
tolaisista valtioon kohdistuvista kritiikeistä huolimatta pandemia-aika on monen muun kriisin tavoin ollut voittopuolisesti aktiivisemman valtion puolustamisen aikaa.

Pandemian voikin sanoa kärjistäneen valtioon liitettyjä ristiriitaisuuksia. Alberto Toscano (2020) on puhunut paradoksaalisesta "valtion halusta". Termi on alun perin sekä Michel Foucault'n että Gilles Deleuzen ja Félix Guattarin tahoillaan muotoilema teesi, jonka mukaan valtiollisen hallinnan suuntaa ei pidä ajatella vain ylhäältä alas vaan se täytyy nähdä myös tietyissä tilanteissa täydellisesti ympärikäännettynä - ilmaantuu "valtava, täyttymätön jano, joka pakottaa ihmiset kääntymään valtion puoleen”, kuten Foucault eräässä haastattelussaan (Foucault 1978) toteaa. Tällä termillä on paikkansa sekä Foucault'n että Deleuzen ja Guattarin hallinnallisuuden ja kontrollin analyyseissä, mutta Toscano kytkee sen valaisevalla tavalla pandemiatilanteeseen. Hänen mukaansa on oleellista, että valtion halu ei liity vain kysymykseen markkinoiden ja valtion välisestä suhteesta tai työnjaosta, vaan taustalla on laajempi filosofinen kiista siitä, millä tavalla valtiokeskeinen Leviathanin malli on edelleen, kaikesta aikamme yksilökeskeisyydestä huolimatta, poliittisen ajattelun perustava lähtökohta.

Valtion halu ei ole kuitenkaan puhtaasti pandemiaan sidottu paradoksaalinen ilmiö vaan se on leimannut etenkin yhteiskuntateoreettista ajattelua jo pidemmän aikaa. Viimeistään väitetystä totuudenjälkeisestä ajasta lähtien kriittiset ajattelijat ovat löytäneet itsensä tilanteesta, jossa esimerkiksi kansanterveyden todellisia motiiveja kyseenalaistavat myös erilaiset salaliittoteoriat. On edelleen ylläpidettävä valistuneen yksilön kriittistä suhtautumista valtiollisen esivallan näennäisesti universaaleihin ja pyyteettömiin intresseihin, mutta mitä tahansa vaihtoehtoisia faktoja ei tulisi uskoa. On muistettava esimerkiksi kansallisvaltioiden harjoittaman lääketieteellisen biovallan synkkä historia, mutta rokotteesta kieltäytyminen on kuitenkin kaikkien faktojen valossa äärimmäisen vastuutonta ja typerää.

Yksi yritys artikuloida tämä ristiriita pandemian kontekstissa on ollut ajatus "demokraattisesta biopolitiikasta". Siinä missä biopolitiikan keinovalikoima esimerkiksi Michel Foucault'n ja Giorgio Agambenin ajattelussa on pohjimmiltaan jotain hyvin epäilyttävää verhottuna kansanterveyden parhaaksi, kohtaamme biopolitiikan merkityksen nyt hyvin eri tavalla. Kyseessä on poliittinen epidemologia alhaalta ylös, yritys siirtyä historiallisesta kritiikistä kohti affirmatiivisempaa suhtautumista esimerkiksi valtiollisiin rokoteohjelmiin demokraattisen elämänmuodon mahdollistajana, ei ainoastaan alistavana väestönkontrollina.

Tämä merkitys näkyy monella eri tasolla. Laajassa merkityksessä kaikki elämänmuodot ovat pohjimmiltaan riippuvuussuhteessa toisiinsa. Siksi ihmisten demokraattinen yhteiselo edellyttää ontologisella tasolla jaettua biopolitiikkaa, johon elämänmuoto on sitoutunut kokonaisuudessaan kokonaisuuden hyväksi. Tästä näkökulmasta juuri yksilön aktiivinen, vastuullinen ja refleksiivinen suhtautuminen biopolitiikkaan on nimenomaisesti kriittisen ajatteluperinteen parhaiden puolien jatkamista. Siten on myös täysin perusteltua tuomita etenkin rokotekriittisyys - vaikka biopolitiikan historian suhteen asia ei olisikaan täysin yksiselitteinen. Kapeammassa mielessä demokraattinen biopolitiikka on pandemian yhteydessä viitannut myös esimerkiksi keskinäiseen apuun sekä yhteiskunnallisiin liikkeisiin: on kamppailtava sen puolesta, että myös siirtolaisilla ja paperittomilla on oikeus pandemian aikana terveyspalveluihin, turvallisiin elinoloihin sekä rokotteisiin, siis oikeuteen päästä valtion kansanterveyden piirin. 
Toiseksi, valtiosta on myös tullut viime vuosikymmeninä, kaikesta valtionvastaisesta teoreettisesta ajattelusta huolimatta, käytännössä ainoa tapa haastaa uusliberaali talouden ylivalta. Siinä missä vuonna 2008 puhjennut talouskriisi vauhditti keynesiläisyyden uutta tulemista, keskustelu on myöhemmin siirtynyt ekologiseen jälleenrakentamiseen. Esimerkkinä tästä on historiantutkija Andreas Malmin Corona, Climate, Chronic Emergency -teos, joka laajentaa keskustelun valtion halusta pandemiatilanteessa kohti laajempaa ekologista kriisiä. Malmin teoksen ansio on sen painopiste kysymysten mittakaavassa: ilmastokriisiä, kuten koronakriisiä, ei ratkaista ainoastaan yksilöiden teoilla, kompensoimalla lentomatkan hiilijalanjälkiä tai jatkamalla etätöitä hetken pidempään. Tarvitaan rakenteellisia ratkaisuja, valtioiden kykyä kahlita fossiilitaloutta.

Onko valtion rooli tilanteen ratkaisijana kuitenkaan näin yksinkertainen? Malm nimittäin vaikuttaa liittävän valtioon niin suuren latauksen toivoa, että se estää häntä näkemästä valtion ja markkinatalouden monimutkaisempaa suhdetta. Kriittisempi valtioteoreettinen näkökulma korostaa valtion ja markkinoiden rakenteellista yhteyttä etenkin yhteiskunnallisten kriisien aikana. Aktiivisen valtion paluu on poikkeusaikana ennen kaikkea odotettu ja looginen seuraus, ei varsinainen paradigmanmuutos (Jappe et all 2020). Malmin toiveikkaan jäsennyksen voikin nähdä toistavan kaavaa: samoin kuin historiallisesti erilaiset valtion roolia korostaneet sotatalouden muodot eivät pohjimmiltaan kyseenalaistaneet vapaiden markkinoiden yhteiskunnallista roolia, myöskään Malmin valtion roolia korostava teesi ei ainakaan historiallisesti ole niin radikaali kuin miltä näyttää.

Tästä näkökulmasta olennaisempaa kuin katsoa valtioiden ja markkinoiden välistä suhdetta ja sitä miten tämä dynamiikka eroaa normaaliaikoina ja kriisiaikana (ja voitonriemuisesti julistaa, että"tarvitsemme edelleen hyvinvointivaltiota"), onkin tutkia, miten myös valtion instituutioiden rakenteellista suhdetta talouteen voidaan ajatella perusteellisesti uudella tavalla pandemiatilanteen jälkeen. Tällaisen tarkastelun voi sanoa olevan edellytys myös ekologisen kriisin nopealle hillitsemiselle.

\section{SUURTEN LUKUJEN POLITIIKKA}

Pandemia-ajan yhteiskunnallista keskustelua ovat hallinneet suuret luvut. Media ja tieteelliset selvitykset ovat ymmärrettävästi toistelleet erilaisia tilastollisia esityksiä siitä, mitä maailmalla tapahtuu: pandemian syntyä ja etenemistä on seurattu taulukoista ja graafeista ja maiden, alueiden ja jopa kaupunginosien tilanne on käsitetty sitä kautta, kuinka punaisina ne on kuvattu pandemian vakavuutta kuvaavissa kartoissa. Erityistä on lukujen suuruusluokka: maailman mittakaavassa pandemian uhrien lukumäärät, tartuntojen määrästä puhumattakaan, ovat hillittömiä - niiden suhteuttaminen vaatii menemistä hyvin kauas historiaan.

Koronapandemian kaltaisessa äärimmäisen vakavassa tilanteessa voi toki vaikuttaa turhanpäiväiseltä pohtia tieteellisen ja objektiivisen tosiasian ja niin sanotun sosiaalisen faktan välistä eroa. Voisi kuitenkin väittää, että tilastollisen tiedon rooli on ollut pandemiatilanteessa niin korostunutta, että se pakottaa vähintäänkin muistuttamaan, että pandemian yhteiskunnallisen ilmiön erottaminen ikään kuin "luonnollisesta" tosiasiasta on välttämätöntä. Pandemiatapahtuma ei ole sellaisenaan mikään luonnonvoima, hyökyaalto tai maanjäristys. Tämän huomion ei 
pitäisi vähentää lainkaan pandemian todellisuuden vakavuutta - saati antaa tilaa salaliittospekulaatioille. Päinvastoin: yhteiskunnallista pandemiailmiötä koskevan keskustelun ja teoretisoinnin painottuminen tilastollisiin tosiasioihin on ymmärrettävää, mutta on myös tunnistettava tämän painotuksen taustalla tapahtuva ilmiön tuottaminen, sen objektivoinnin logiikka. Vain näin voidaan saada ote siitä, mitä pandemian aikana varsinaisesti tapahtuu.

Nyt "pandemian lopun alussa" eli massamittaisen rokottamisen kynnyksellä tämä huomio korostuu. Pandemioiden, rokottamisen ja tilastotieteen yhteys ei nimittäin ole satunnainen. Kuten yhteiskuntatieteissä on osoitettu, rokottaminen on kansanterveydellisenä keinona erottamaton väestö- ja tilastotieteellisistä tarkasteluista. Oleellista on, että rokottaminen ei ole suorassa suhteessa sairauteen luonnollisena tosiasiana vaan sen vaikutus ikään kuin kiertää yksilöön väestöllisen tason kautta: rokottamisella pyritään pienentämään sairastumisen todennäköisyyttä, mikä tarkoittaa sitä, että tarkastelun lähtökohtana on tietty joukko, jossa vertailuja rokotettujen ja rokottamattomien välillä voidaan tehdä. Rokottamista ei siis voi käsittää ilman riskin käsitettä ja tilastotieteen yhteiskunnallisen merkityksen huomioimista.

Tilastotieteillä on valtava merkitys nykyaikaisissa valtiollisen hallinnan teorioissa ja käytännöissä ylipäätään. Mutta erityisesti koronaviruspandemiaa voisi kutsua "suurten lukujen politiikan" ajaksi. Ilmaus on peräisin klassikoksi muodostuneen Alain Desrosières'n teoksen (1993) nimestä. Teoksen oleellinen väite on, että tilastotieteen roolina ei ole olla mikään neutraali sivustaseuraaja ja ilmiöiden havainnollistaja. Sen sijaan tilastotiede on tekijä, joka tuo politiikkaan suurten lukumäärien tason ja tätä kautta ylipäätään luo "julkisen keskustelun”, siis tavan luoda ja jakaa tietoa, joka on kaikkien yhtälailla saatavissa ja ymmärrettävissä.

Yhteiskunnallisen ajattelun filosofisemmat teoriat painottavat tyypillisesti ajatusta siitä, että yleisesti jaettavissa oleva julkisuus rakentuu kaikkien ihmisten ideaaliselle mahdollisuudelle ja kyvylle sanoa sanansa ja keskustella poliittisen yhteisön avoimella agoralla. Usein vedotaan läntisten yhteiskuntajärjestysten alkuun antiikissa tai humanistiseen ihmisen poliittiseen olemukseen. Desrosières'n mukaan modernin julkisen tilan ja yhteiskunnallisen keskustelun paikan historia on kuitenkin toinen. Se syntyy elimellisessä yhteydessä tilastotieteiden synnyn kanssa 1700-luvulta alkaen: tilastollinen tieto ei putoa taivaasta kuvaamaan valmiina odottanutta maailmaa vaan luo sen ensimmäistä kertaa julkisena. Julkisen keskustelun tila on erottamaton tilastollisen tiedon olemuksesta, joka on samaan aikaan poliittis-hallinnollinen kuvaus yhteiskunnan ilmiöistä ja tapa käsittää hallitsematon moninaisuus ja tulevien tapahtumien satunnaisuus. Tämä teesi on sanottu monilla muillakin termeillä - esimerkiksi Ian Hackingin ansiosta ymmärrys tieteen todellisuutta konstruoivasta kehävaikutuksesta on nykytieteenfilosofian valtavirtaa - mutta Desrosièresia kiinnostaa nimenomaan tilastollisen tiedon osuus siinä, mitä julkisen keskustelun piiri politiikan alueena on.

Desrosières'n väite ei siis ole puhtaan tieteenfilosofinen teesi siitä, kuinka tieteen omat käytännöt vaikuttavat sen tutkimiin objekteihin, vaan väite käsittelee sitä, kuinka julkisen tilan tarjoama tiedon demokraattinen avoimuus syntyy tilastollisen tiedon ja päättelyn mahdollistamana. Yhteiskunnallisen ajattelun kannalta onkin niin, että julkinen keskustelu - jota yhteiskunnallinen ajattelu itsekin on täytyisi käsittää lähtien tästä yhtä aikaa institutionaalisesta ja tieteellisestä genealogiasta, joka toisin kuin julkinen keskustelu, ei ole konsensushakuinen vaan täynnä eri paradigmojen välisiä jännitteitä. 
Kun koronaviruspandemia kaikkia koskettavana tosiasiana todella vaatii sitä, että tilannetta kuvataan avoimesti ja vakuuttavasti kaikille, voi olla paikallaan huomata, että puhe tilanteesta ja tosiasioista nimenomaan suurina lukuina, tilastollisina objekteina, ei suinkaan ole sattumaa. Kiinnostavaa onkin kysyä, millä tavalla pandemiatilanteen äärimmäinen julkisuus, se että tilanne todella koskettaa kaikkia, kärjistää julkisen tilan ja poliittisen päätöksenteon toiminnan ja ehkä siten tuo korostetusti ilmi sen kytkennän tilastolliseen tietoon.

Politiikan ja tieteen välisen suhteen kannalta on oleellista, että tilastollisille menetelmille perustuvan mallintamisen rooli on nykyään korostunut. Kuten tämän pandemiateeman ensimmäisessä numerossa julkaistussa Stefano Canalin ja Saana Jukolan (2020) artikkelissa käytiin havainnollisesti läpi, pandemiatilanne on nostanut esiin mallintamiseen ja näyttöön perustuvaan politiikkaan liittyviä ongelmia, joiden syyt voi jäljittää menetelmien sisäisiin metodologisiin ja matemaattisiin kysymyksiin. Suurten lukujen politiikan tilastollisuudesta kumpuavana erityispiirteenä voisi pitää myös sitä, kuinka yhteiskunnallisten ratkaisujen vaikutusten arviointi vaatii aina vielä vähän enemmän aikaa, loputtomia tarkennuksia ja suuria tapausmääriä.

Poliittisen subjektin ja yksittäisen ihmisen kokemuksen kannalta suurten lukujen politiikan voisi myös sanoa joutuvan pandemiatilanteessa tiettyyn oikosulkuun, joka yllättäen paljastaa yhteiskunnan järjestyksen takaavan "tilastollisen järjen". Tilastollisiin faktoihin nojaava julkinen keskustelu luo sellaisia käsityksiä ihmisten elämästä, että ne eivät määritelmällisesti voi vastata kenenkään kokemusta nimenomaan siksi, että ne ovat tilastollisia normaaleja ja keskiarvoja - mikä on omiaan antamaan kokemuksen siitä, että yhteiskunnan järjestys on olemukseltaan täysin mekaaninen, jotain täysin toista suhteessa elettyyn elämään.

Ei siis ole ihme, että pandemioihin ja rokotuksiin kohdistuneet epäilykset ja vastaliikkeet suuntautuvat usein nimenomaan tilastollisen tiedon valtaan ja uskottavuuteen. Nadja Durbach on teoksessaan Bodily Matters selvittänyt sitä, miten rokotevastaisuus ilmeni 1800-luvun lopun Englannissa kamppailuna kahden ruumiillisuuden välillä: vastakkain asettuivat yhteistä hyvää edustava tilastollinen normaali ja ihmisten omakseen kokema ruumis, jonka hallintaa rokote uhkasi. Rokottaminen onkin tilastotieteen roolin suhteen erityisen valaiseva esimerkki: rokotteen kaksi tulkintaa yhteisen hyvän instrumenttina - uhkaavana biovaltana ja teknologisena pelastuksena - saavat aikaan sen, että rokote näyttäytyy sekä kaikkien salaliittoteorioiden Pandoran lippaana että ihmeellisenä valtion haluun vastaavana taivaanlahjana. Tämän skeeman ulkopuolella rokote on väestönhallinnallinen asia, joka ei oman ruumiin terveyden kannalta anna mitään muuta kuin mahdollisen muutoksen sairastumisen todennäköisyyteen, joka puolestaan määrittyy tilastollisen normaaliruumiin kautta.

\section{YHTEISKUNNALLISEN AJATTELUN ROOLISTA}

Historiallisesta näkökulmasta koronaviruspandemiassa ei ole mitään uutta - jos jotakin voi kutsua ikiaikaiseksi vitsaukseksi niin nimenomaan kulkutauteja. Katastrofeilla sen sijaan on usein nähty olevan tietty opetus. Kiinnostavaa on, että ajatus katastrofista onkin suhteellisen uusi asia: kun ensimmäisiä katastrofeja sa- 
notaan olleen Lissabonin ja Calabrian maanjäristykset 1755 ja 1784 sekä ruutitehtaan räjähdys Pariisin laitamilla 1794, oleellista on niiden luoma yhteiskunnallinen epäjärjestys ja ihmisen oman toiminnan osuus tapahtumien kokonaisuudessa, ei niinkään onnettomuus sinänsä. Katastrofi tyrmää siten uskon ajan jatkuvuuteen ja edistykseen. Onko koronaviruspandemia tässä suhteessa katastrofi? Onko sillä jokin opetus?

Jos yhteiskunnallisen ajattelun ymmärtää kaikkein yleisimmällä tasolla, vaikuttaa siltä, että se jakaantuu kolmeen. Yksi käsittää tehtäväkseen julistaa, että tulipa eteen mitä tahansa, matka jatkuu ja toivoa on - tosin oleellista on että nämä päämäärät ja toivot jäävät mysteereiksi. Tällainen hämärä ajattelu pitää kiinni siitä, että kaikelle on lopulta syynsä, tuntemattomat toki, ja että ajattelun tehtävä on itse asiassa sekä muistuttaa näiden syiden tärkeydestä että vaalia niiden viime kätistä selvittämättömyyttä. Toista voisi nimittää kriittiseksi tai reaktionaaliseksi. Se ei ota kantaa siihen, mitä on tulossa tai mitä pitäisi tehdä, vaan käsittää tehtäväkseen purkaa tapahtumien taustoja ja mahdollisuusehtoja. Vähintäänkin rivien välissä se pitää tiukasti kiinni siitä, että mitään ei tapahdu, mikään ei todella muutu. Kolmas taas lähtee siitä, että maailman kulku katkeilee, hyppii ja hajoaa eri suuntiin. Oleellista on että tämän tyyppiset avaukset lähtevät siitä, että maailmassa tapahtuu muutoksia, joita ei voi peruuttaa, siirtymiä joiden jälkeen menneeseen ei ole paluuta, ja että näistä siirtymistä avautuvat suunnat ovat tulosta kamppailuista, joissa on osansa niin poliittisilla päätöksillä kuin tieteelläkin.

Mitä pandemia-aika sitten teki, mitä sellaista sen aikana tehtiin, että paluu edeltävään aikaan ei enää ole mahdollinen? Mikä on pandemian opetus? Usein tällaisen kysymyksen esittäminen nimenomaisesti estää siihen vastaamisen, koska tällöin ajatellaan tapahtumien jo jääneen taakse ja ihmiskunnan edistyneen taas askeleen kohti parempaa. Virus itse ei kuitenkaan välitä opetuksista, se vain jatkaa muuntuneena leviämistään. Kysymys viruksen aikaansaaman pandemian vaikutuksista koskeekin yhteiskunnallisen elämän kokonaisuutta ja sen tutkiminen taas on osallistumista kamppailuun, joka on vasta hahmottumassa.

Kädessäsi on Tiede E̋ edistyksen Pandemia-teemakokonaisuuden jälkimmäinen osa: ensimmäinen osa julkaistiin numerossa 3/2020. Seitsemän vertaisarvioitua artikkelia ja kymmenkunta laajaa tutkimuksellista puheenvuoroa sisältävä teemakokonaisuus tarkastelee koronapandemiaa ja sen yhteiskunnallisia seurauksia monitieteisesti, kriittisesti ja laaja-alaisesti. Toimittajina tavoitteenamme on ollut mahdollistaa kokonaisuus, jossa pandemian ravisuttamaa maailmaa lähestytään sekä yhteiskuntateoreettisten että empiiristen tutkimuspainotusten avulla. Tässä mielessä voi ajatella, että teemakokonaisuus on ikään kuin ikkuna laajempaan yhteiskunnallisen ajattelun ja tieteellisen tutkimuksen kohtaamaan uuteen tilanteeseen, jossa oli kyettävä tekemään nopeasti selkoa ohi kiitävistä tapahtumista, tieteellisestä näytöstä ja siihen liittyvistä tulkinnoista, suurista väitteistä ("tämä muuttaa kaiken"), poliittisten päätösten epävarmuudesta ja arjen poliittisista konflikteista. Toisaalta teemanumero ajoittuu sen verran etällle kaikkein hektisimmästä koronakeväästä, että numeron kirjoittajat ovat pystyneet ottamaan tutkimaansa kohteeseen tarpeellista harkintaetäisyyttä ja punnitsemaan tarkasteluaan toisen aallon ja jopa "pandemian lopun alun" häämöttäessä. 
Uskallammekin luvata, että tämän teemakokonaisuuden tekstit eivät tarjoa vain erinomaista näköalaa siihen, mitä pandemian aikana on tapahtunut, vaan kokonaisuus luo hyvät edellytykset tarttua siihen poliittisten kiistojen maastoon, joka avautuu tulevina vuosina pandemian lopun alun jälkeen. Yhteiskunnallisen ajattelun ja monitieteisen tutkimuksen nopeaa mobilisointia tarvitaan silloin, kun kriisi on käsillä. Toisaalta turvalliseksi vakuuteltu normaali ja siihen takaisin lipsuminen vaativat kriittiseltä ajattelulta ja tutkimukselta jopa kriisiaikaa enemmän. Onhan nimittäin niin, että juuri normaali saattelee planeetan, luonnon ja ihmisyhteisöt kiihtyvällä tahdilla entistä vakavampien kriisien partaalle.

Tämän numeron avaavassa artikkelissa Ari Hirvonen tarkastelee koronaviruksen poliittista epidemiologiaa eli sitä, miten "biologinen oleminen tunkeutuu poliittiseen olemiseen”. Atte Harjanne, Helmi Räisänen ja Jussi T. Eronen tutkivat Suomessa koronakeväänä toteutettua kriisinhallintapolitiikkaa tulevien vuosien kiireellisten ympäristöpoliittisten muutosvaatimusten näkökulmasta. Hanna Kosunen, Tiina Hotakainen ja Essi Oikarinen tutkivat, miltä koronaviruksen rajoittamisen politiikka näyttäytyi kahden eurooppalaisen pääkaupungin julkisen tilan ja katujen hallinnan näkökulmasta. Numeron viimeisessä artikkelissa Johanna Järvinen-Tassopoulos, Virve Marionneau ja Tuulia Lerkkanen avaavat näkökulman rahapelaamiseen maailmaan.

Numeron viidessä laajassa puheenvuorossa puolestaan tarkastellaan näyttöpohjaisen politiikan ongelmia kriisioloissa, viruksen biologista olemusta, epidemiakuvauksia maailmankirjallisuudessa, Jean-Luc Nancyn pandemiatulkintaa, ja epidemiahistorian esittämistä koronan aikaisessa mediakerronnassa. Numeron taiteilijana on Maaria Jokimies.

Teemanumeron kirjoittajat ovat tehneet kiitettävää työtä paitsi vangitessaan poikkeuksellisen vinhassa liikkeessä olleen tutkimuskohteen laadukkaaksi analyysiksi myös viimeistellessään sinnikkäästi tekstejään tiukalla aikataululla. Kirjoittajien lisäksi kiitämme kokonaisuuteen pyyteettömän panoksensa antaneita vertaisarvioitsijoita. Suomalainen tieteellinen yhteisö ei olisi elinvoimainen ilman tutkijoiden vapaaehtoista työtä tutkimusten vertaisarvioinnin eteen. Arvioitsijat tekivät työtään paikoitellen hurjissakin aikavaatimuksissa, lainkaan laadusta tinkimättä.

NUMERON TOIMITTAJAT ARI KORHONEN, ALEKSI LOHTAJA JA TERO TOIVANEN

KIRJALLISUUS

Desrosières, Alain (1993) La politique des grands nombres. Histoire de la raison statistique. La Découverte, Pariisi.

Durbach, Nadja (2005) Bodily Matters. The anti-vaccination movement in England 1853-1907. Duke University Press, Durham.

Foucault, Michel (1978) "Méthodologie pour la connaissance du monde: comment se débarrasser du marxisme". Teoksessa Dits et Écrits III, 1976-1979. Gallimard 1994, 618.

Jappe, Anselm, Sandrine Aumercier, Clément Homs \& Gabriel Zacarias (2020) De Virus Illustribus. Crise du Coronoavirus et épuisement structurel du capitalisme. Crise \& Critique, Albi.

Toscano, Albert (2020) "The State of the Pandemic". Historical Materialism 28:4, 3-23.

Canali, Stefano \& Jukola, Saana (2020) "Näyttöön perustuvan pandemiapolitiikan haaste". Tiede $\Xi^{\circ}$ edistys 3/2020, 212-227. 